\title{
Sustainable Development and a Dwindling Carbon Space
}

\author{
Hans Opschoor
}

Accepted: 22 October 2009 / Published online: 14 November 2009

(C) The Author(s) 2009. This article is published with open access at Springerlink.com

\begin{abstract}
Curbing global warming by setting long term maxima for temperature rise or concentrations of greenhouse gases defines spaces within which further emissions of these gases are to remain (referred to here as 'carbon spaces'). This paper addresses questions related to how to share between countries the carbon space and/or efforts to stay within it, in the perspective of sustainable development; different allocation mechanisms are reviewed, responding to criteria such as 'responsibility' for climate change, 'capability' to engage in abating it, and 'potential' or future contribution. The carbon space remaining at any time will depend on effective mitigation up till that time, and will condense if more stringent maxima are to be set; per capita this space becomes smaller with rising population. Sharing the carbon space in a fair way requires "convergence" of currently widely unequal per capita emissions. If the world is to stay within the carbon space consistent with $<2^{\circ}$ warming, then developed economies - the wealthiest sources of greenhouse gases should quickly and deeply engage in mitigation. Also, substantial mitigation is to take place in developing countries and that this will require substantial support to developing countries (financially, technologically). Changing development paths can make a major contribution to climate change mitigation; this requires changes in investment, production and consumption patterns. Green New Deals as proposed in the context of a widened response to the current economic crisis could become a first phase of a fundamental transition towards a decarbonised global economy worldwide. Concerns to do with equity as well as sustainability must be incorporated and integrated into coherent transitory strategies.
\end{abstract}

Keywords Carbon space - Climate change - Sustainable development · Burden sharing . Differentiation

This paper was delivered as the author's Valedictory Address to the ISS on 4 June 2009.

H. Opschoor $(\varangle)$

Department of Economics of Sustainable Development, Institute of Social Studies (ISS),

Postbus 29776, 2502 LT Den Haag, The Netherlands

e-mail: opschoor@iss.nl 
"The world is facing a global climate crisis that requires urgent ... action " (South Centre 2007). UN SG Ban Ki-Moon has called climate change a "defining issue of our era". These are political assessments but they are based on a wealth of scientific data collected in four 5-yearly assessments by the Intergovernmental Panel on Climate Change (e.g. IPCC 2001, 2007). Developing countries are more vulnerable to climate change and have relatively less capacity to adapt to its impacts-despite having had little to do with causing climate change until recently-and this has occupied me the last decade or so in the context of IPCC, and the UN Committee of Development Policy (see e.g. CDP 2007, 2009).

The growing agreement on these matters does not mean that it is clear what is do be done about them and who is to do what. Clearly the costs of adaptation to climate change need to be covered and it seems obvious that this is done in accordance with some measure of fairness. But if the world wants to avoid the nastier types of damages it needs to avoid atmospheric warming beyond certain levels. That will limit the space for further emissions of carbon dioxide and other greenhouse gases. With growing numbers of people and rising average levels of welfare it gets very crowded in the carbon space and the claims on it are growing rapidly. In this address I will look at how to share that space and/or efforts to stay within it (Sects. 4-7) in the perspective of sustainable development (Sect. 8), but before that I want, in Sects. 1-3, to 'contextualise' the climate crisis, give some details on it and the way it is being approached politically, and define 'sustainable development'.

\section{Global Economic Development: Uneven, Unsustainable and Unstable}

We live in a world plagues with dilemmas, crises and trends that move it away from what most people thinking about this see as the global common goods. Starting with an issue that has always been a deep concern at ISS, world inequality has been reported as "high and rising" (Ocampo and Vos 2008; see also UNDP 2002). Ocampo and Vos (ibid.) conclude that there is no automatic tendency towards income convergence and that differences in initial conditions tend to be exacerbated by the inequitable functioning of world markets (ibid). That statement brings us to an underlying process: that of globalisation, especially in the form it increasingly took after say 1970: that of liberalisation, deregulation and several other goodies that neo-liberal ideology had in store, such as the global advance of an increasingly free market system. As Milanovic (2005) pointed out: the openness that globalisation calls for may exacerbate inter-country inequality and is likely to increase inequality in poor countries-which, in the long run, is socially unsustainable.

Globalisation in the neo-liberal mode also adds to the propensity of economic development to be unsustainable in an ecological sense. We see manifestations of that in the emerging problems with fisheries, water scarcities, competition over land use, food crises. We also see it in the domain of climate change. Measured in one particular way (that of the so-called 'ecological footprint') the world is calculated to now consume $25 \%$ more of those resources than the planet's capacity to regenerate them (its 'biocapacity', or 'environmental space'); it can do so only at the expense of its reserves in terms of natural stocks and capacities.

Systemic features underlying these various global crises and dilemmas include:

- Virtually unaccountable economic agents operating on socially and politically "unembedded" (Altvater 2009) markets (un"submerged", as Polanyi (1944) called them), beyond any form of co-ordination and direction; 
- an enhanced short-sightedness in political and economic systems, already denounced some 90 years ago by welfare economist Pigou (1920, 1962 reprint: I.II.3) as a 'defective' (and even 'perverted') 'telescopic faculty' leading to a shifting of social costs of private enterprise on to future generations;

- a prevailing culture and ideology supportive of market forces driven economic growth, rather than of rights based human development and responsibility for today's weak, for future generations and for biodiversity.

The current economic recession has augmented the concern over the cracks in the global economic system fire. By the end of 2008 it had triggered the realisation the international community was to go for a New Bretton Woods (Gordon Brown), a New Multilateralism and a "more inclusive and sustainable globalization" (Zoellick 2008), new green policies and a system that would put these in place.

Dealing with the entire set of crises in a coherent way will require a new orientation of development - this time in countries North as well as South-and systemic reforms. I do not have the possibility to address here the fundamental systemic aspects but will look at a number of economic process-oriented aspects. If we are to see-globally, but especially in the developing countries-sustainable and equitable economic development, then we will need structural change in world economic activities.

Such structural change needs to include - and now I come to my key theme-a transition to a carbon free (or at least carbon poor) pattern of economic development, clean in terms of its content of greenhouse gases, and lean in terms of its energy and land use. Some see that as a 'green new deal' in the face of the current economic crisis-killing two birds with one stone: warming as well as unemployment.

\section{Climate Change: and Climate Change Negotiations: A Helicopter View}

Climate change may result from natural processes but the current levels of warming are to a large extent due to human activity (IPCC 2007): emissions of so-called greenhouse gases (GHGs) amongst which notably Carbon Dioxide $\left(\mathrm{CO}_{2}\right)$. This gas is emitted through energy use (especially fossil fuels) and changes in land use (about $70 \%$ and $30 \%$ respectively). I shall focus on energy-related emissions, of $\mathrm{CO}_{2}$ in particular. $\mathrm{GHG}$ emissions lead to a building up of GHG-concentrations in the atmosphere that give rise to a range of phenomena such as atmospheric warming, changing weather regimes, ice cap melting, sea level rise etcetera. These, in turn, generate impacts on natural and social systems, such as changing natural resource supplies, with adverse impacts on food and water, biodiversity and human health.

Since the Industrial Revolution over 500 billion tons of Carbon (almost 1850 billion tonnes of $\mathrm{CO}_{2}$ ) have been released in the atmosphere, primarily by the industrialised countries; the current level of annual C-emission is about 9 billion tons. Table 2 (left hand side) shows the shares in emissions of different countries and global regions. Currently global warming is at $.7^{\circ} \mathrm{C}$ above pre-industrial levels; with economies developing in a 'business as usual'-mode (BAU), temperatures would be up 5 to $6^{\circ} \mathrm{C}$ by 2100 , with catastrophic social and ecological impacts (IPCC 2007; CDP 2007).

The main responses to climate change are directed at dealing with the effects of it ('adaptation') or reducing the emissions that give rise to it ('mitigation'). In this address I will focus on mitigation and how that involves or may involve developing countries.

In the Framework Convention on Climate Change (UNFCCC 1992) countries have agreed to co-operate towards achieving stabilization of concentrations of greenhouse gases at a level 
that would prevent "dangerous anthropogenic interference with the climate system, within a time frame sufficient to allow ecosystems to adapt naturally, ..., and to enable economic development to proceed in a sustainable manner" (adapted from FCCC, art. 2; italics mine). The 1997 Kyoto Protocol intended to elaborate and implement this Convention in the context of a framework including objectives for emissions reductions in 2012 for developed ("Annex I") countries. In 2007 the Bali Action Plan (BAP; UNFCCC 2007) was established by the parties to UNFCCC, to arrive at a new agreement in Copenhagen, 2009, on cooperative action on climate issues beyond 2012. Developed countries are to accept commitments in mitigation, technology transfer, and in facilitating adaptation and mitigation efforts in developing countries beyond what these countries consider 'appropriate' in terms of their domestic mitigative actions. Details and extent of these commitments are currently being negotiated.

There appear to be thresholds in predicted impacts that suggest the desirability of caps on warming at $2^{\circ} \mathrm{C}$ by 2100 . Internationally, there is a growing sense that this is an appropriate target. If adopted, this could be taken as an expression of the global concern over its intertemporal and intergenerational ethical responsibilities in the climate domain. Recently disclosed evidence on melting of ice in e.g. Antarctica suggests that a maximum of appr. $1.5^{\circ} \mathrm{C} \mathrm{might}$ be more appropriate. Staying below such levels of warming will require massive emission reductions at an unprecedented scale: going towards a carbon-free global economy, replacing fossil fuels by non C-containing alternatives (solar, wind, etcetera), reducing the energy-content of production and consumption It may also affect income levels and lifestyles of the wealthy and the middle classes. Technicians tell us (e.g. Pacala and Socolow 2004; Stern et al. 2006; Bierbaum et al. 2007) that keeping warming below $3^{\circ}$ is possible, and even $2^{\circ}$ may be, with advanced versions of currently available technologies, but that will be far from easy and may even generate various other problems (nuclear waste-related problems, competition over agricultural land, etcetera). Further innovation must be achieved-most definitively so if targets below $2^{\circ} \mathrm{C}$ are to be met and if economic growth is to continue.

The cost of going for $2-3^{\circ}$ maximum over the next 1-2 centuries may amount to the equivalent of a 1-2\% GDP loss per annum (Stern et al. 2006; UNDP 2007). Would that be that worth it? Stern calculated the costs of inaction and found these under certain, sometimes far-fetched, assumptions to be 5 and even up to 20 times higher than the costs of mitigation as calculated by him (Stern et al. 2006). So, at the global level, curbing warming below $2^{\circ}$ seems to be not only affordable as a premium worth paying to avoid sometimes catastrophic risks and associated damages but possibly even desirable in an enlightened and future oriented cost-benefit analysis. However, temperatures would still go up, due to the fact that GHGses will stay in the atmosphere often for long periods of time. So inevitably there will be increasing impacts that societies will have to live with and adapt to. Adaptive capacity depends on the social and economic development level and here again poor countries are less well endowed. Adaptation will impose more of a burden the longer the world will wait with deep mitigation.

If the transition towards a carbon free or GHG-poor society is not effectively done, other options considered might be interim ones like Carbon Capturing and Storage e.g. in old oil and gas fields. Beyond that, new, unproven and potentially very risky technologies in the domain of 'geo-engineering' have been proposed (e.g. large scale interventions in the atmosphere or even beyond, aiming at diverting solar radiation by mirrors in space, or reducing atmospheric carbon dioxide concentrations e.g. through ocean iron fertilization). I will not explore this Prometheusian approach further here.

This leaves us with a final question: who is expected to do what in order to arrive and ensure positions within the carbon space? That, to a large degree, is the substance of the current negotiations towards a new global deal to replace the Kyoto Protocol, in Copenhagen, by the 
end of 2009. The first draft of a negotiation text is being discussed in Bonn as this valedictory address is presented, but progress is uncomfortably slow. Any global compact must provide a credible approach that is in the interest of the South. Some of the factors accounting for the present lack of progress are rooted in a deep deficit of trust between negotiating parties. Some crucial questions are:

- How and how much will the developed countries contribute to the unavoidable adaptation burden resulting from the past, energy intensive economic growth in the North?

- How will mitigative actions by developed countries affect development in developing and emerging economies?

- Why should developing countries engage in mitigation whilst industrialised countries do not meet their Kyoto targets (or at least: not in its own territory)?

- Why should developing countries be involved at all in mitigation, when it wasn't these countries but the industrialised ones that primarily caused climate-related problems?

- Why would the developing countries trust industrialised ones when they speak of cooperation and assistance for mitigation undertaken by developing countries, while the developed ones in general haven't lived up to their ODA-commitments?

International support for mitigation (and for adaptation) in developing countries and transfer of technology might facilitate their getting involved in mitigation, but only to the extent that the trust deficit is overcome.

Meanwhile, an alternative "road" parallel to the UNFCCC-process has been entered upon: the shortcut of Zoellick's "new multilateralism" (Zoellick 2008) which in fact amounts to extended bilateralism - negotiations between some smaller set of countries, with an associated risk of frustrating the multilateral approach under the Convention. In 2007 the G8 set the goal to halve emissions of greenhouse gases by 2050. During the 2008 Hokkaido Toyako G-8 Summit the "major developing economies" participating in that summit (Brazil, China, India, Indonesia, Korea, Mexico, South Africa) approved this approach and agreed to pursue "... nationally appropriate mitigation actions, supported and enabled by technology, financing and capacity-building, with a view to achieving a deviation from business as usual emissions" (Hokkaido Toyota Summit 2008). The most recent move along this track was President Obama's calling together a "Major Economies Forum on Energy and Climate" (April 2009) where 17 countries discussed climate change (including Brazil, China, India, Indonesia, Mexico, South Africa with the intention to accelerate the UNFCCC process. ${ }^{1}$ Developing countries there insisted that short-term goals were needed promising a cutting back to at least $40 \%$ below 1990 emissions by the year 2020 . The US so far only went as far as suggesting a $15 \%$ below 2005 .

\section{Climate Change and Sustainable Development}

In 1987 the World Commission on Environment and Development published its report to the UN: "Our common future", which launched the perspective of sustainable development, defined as: a process of change in which (i) the exploitation of resources (incl. natural resources), (ii) the direction of investments, (iii) the orientation of technological development, and (iv) institutional change are all compatible and enhance both current and future potentials to meet human needs and aspirations (after WCED 1989:46), by staying within its ecological, economic and social means or capacities. This was translated at the 1992 UN

1 Thus spoke the meeting's Chairman in his "Chair's summary Major Economies Forum on Energy and Climate, April 28th 2009”. US Dep’t of State, Bureau of Public Affairs, Washington DC, April 292009. 
Conference on Environment and Development into an action programme, a set of principles and the signing of two global agreements, one of them (UNFCCC) on climate change.

Prospects for sustainable development in developing countries are adversely affected in three ways (CDP 2009). The first one is: the damages of climate change including the impacts on development (especially the Millennium Development Goals). The second one is the spillovers of policies in the area of climate change undertaken by the industrialised countries. The third one is the effects of the adaptation and mitigation activities by and in developing countries on social conditions and the economies of those countries. The second one of these may require some illustration. That what happens in developing countries is affected by economic activity in industrialised countries generally, is clearly illustrated by the spillovers of the current recession. Climate policies may also have spillovers-some positive, some negative-in developing countries through changed levels and patterns of trade, and in the case of rising energy and carbon prices, which may backfire in the form of adverse regressive, effects on income distributions.

For developing countries to replicate the development path of the industrialised countries with their heavy reliance on carbon-rich energy sources would amount to running into a dead-end street. Rather, these countries should choose other, environmentally more benign development paths directly. Achieving the aims in the international sustainable development agenda will require a drastic reduction in emissions not only in developed countries (who in fact are committed to take a lead in this) but also in developing countries. Developing countries will need assistance in dealing with the impacts of climate change and the adaptation needs that follow from it; they require compensation for damages and risks that are generated largely or fully by already industrialised countries. Capacity building in relation to adaptation is also required.

In the North, an institutional approach to achieving such mitigation is the mechanism of putting a cap on the amount of carbon or greenhouse gases that can be emitted, and to sell (via auctions or direct trading) permits up to that level to those who want to emit. The EU has such a scheme (although it is working far from well), the US is considering it and there are proposals to extend this mechanism to at least the OECD region. This mechanism may not be the most appropriate one for developing countries-most definitely in the less and least developed countries. Developing countries might be more effectively and efficiently (certainly if we disregard fallouts in the form of externalities engendered by market-based mechanisms) involved in mitigation through other schemes. The UN Committee of Development Policy has recently proposed an investment-based mitigation strategy in the perspective of sustainable development (CDP 2007, 2009), to which we shall return below.

\section{Carbon Space: A Compartment in the Environmental Space for Sustainable Development}

After Brundland launched the concept of sustainable development in 1987, I began working on the notion of an 'environmental space' for such development - a space demarcated essentially by the carrying and absorption or sink capacities of the global ecological systems supporting human societies and societal processes (Opschoor 1987). ${ }^{2}$ The concept of "environmental utilization space" (EUS hereafter) represents an abstract virtual reality: a set of

\footnotetext{
2 The EUS was suggested originally as a theoretical notion in dynamic environmental economic analysis (Siebert 1982) and was later proposed as a concept in the development of environmental policy and empirical research (Opschoor 1987, 1992, 1995). By 1995 the EUS was also known as 'ecocapacity' (Weterings and Opschoor 1992) or 'ecospace' (e.g. Opschoor 1995).
} 
bounds or constraints with respect to claims on nature by society at any point in time related to the capacity of relevant support systems and processes in the biosphere, such that society will be able to make such claims in future as well. ${ }^{3}$

The notion of sustainability is an elusive concept; uncertainties on how natural systems behave, and lack of knowledge as to how important the continued existence of these systems is, contribute to that (e.g. Opschoor 2009). Moreover, society may 'expand' its EUS if it successfully engages in the exploration for new resources, in finding new ways to use materials and environmental services, in restoration of degraded resource systems, etcetera. To the extent that 'sustainability' is undetermined, also the boundaries of the environmental space will be vague. Given these uncertainties, some went for simple proxy-measures such as the 'biocapacity' in hectares that is available to human society for its use-the 'ecological footprint' that we already met. Others discerned and investigated sub-spaces such as one for GHGs, or Carbon (the "carbon space"). ${ }^{4}$ This more readily allowed for quantification-and has proven useful in the context of the global climate negotiations. For instance, the South Centre (2007) argued that: “... the environmental and carbon emissions space available for developing countries has been drastically and inequitably reduced by the development pathways taken by today's developed countries....". At the 2008 Poznan climate negotiations the Chinese delegation pointed out that: "Developing countries need carbon space to their industrialization and urbanization". Since then, the notion has been adopted by many other developing countries and CSOs.

One may define the carbon space as the amount of carbon $\left(\right.$ or $\left.\mathrm{CO}_{2}\right)$ that can be put into the atmosphere without this leading to a level of warming — or underlying concentrations of $\mathrm{CO}_{2}$ - that can be considered dangerous (cf. UNFCCC 1992, see above) or otherwise undesirable. So far, the world has not come to an agreed and quantified boundary for this carbon space. Here, to ease the presentation, I will proceed with the $2^{\circ}$-objective as mentioned by EU and South Centre. Figure 1 shows different global spaces for GHGs as trajectories of how conceivably emissions from human activity should develop in the rest of this century to arrive at a situation where several different boundaries on warming will be met (the $2^{\circ}$-cap corresponding more or less with the curve of $450 \mathrm{ppm}) .^{5}$

The magnitude of the challenge can also be shown in numerical terms (Table 1), where $\mathrm{C}$-emissions are decomposed in various contributing components. If by 2100 the world is to be under the $2^{\circ}$-cap and if average incomes and population levels are to be according to expectations, then Carbon per unit of GDP is to be reduced by almost $90 \%$. Implicitly, this amounts to changes in patterns of production and consumption and of energy use, away from Carbon-containing forms of energy. If the mitigation challenge could not be met through a combination of using less energy and using cleaner energy, then the only way to staying

\footnotetext{
3 Sometimes the environmental space is decomposed into national spaces, that interact with one another through spillovers (like downstream river pollution due to upstream sources), but also through trade. In an asymmetric world in terms of power relationships, some countries, through trade, may use other countries' spaces to their disproportionate advantage ('ecologically uneven exchange'). This has become a matter of empirical research-I will not touch upon it further here (except to refer to Anderson and Lindroth 2001 and Rice 2007).

4 This carbon space has been referred to also as: 'carbon budget' (Agarwal and Narain 1991), 'ecocapacity for $\mathrm{CO}_{2}$-emissions' (Weterings and Opschoor 1992), "ecological space for climate change” (MacGregor and Chambwera 2007); the term 'carbon space' was first used-as far as I know- by Parikh and Parikh (2001).

5 These trajectories are surrounded with uncertainties of various kinds. Continuing at the current level of emissions would put into the atmosphere some 360 tons of $\mathrm{C}$ and the chance of exceeding $2^{\circ}$ would be about $70 \%$ (60-85\%); dropping global emissions with $80 \%$ would lead to a risk of exceeding the limit by about $25 \%$ $(10-45 \%)$ (Meinshausen et al. 2009). If only the industrialised countries were to cut their emissions by $80 \%$, then global emissions would be such that the odds of exceeding the temperature limit will be 50\% (30-75\%).
} 


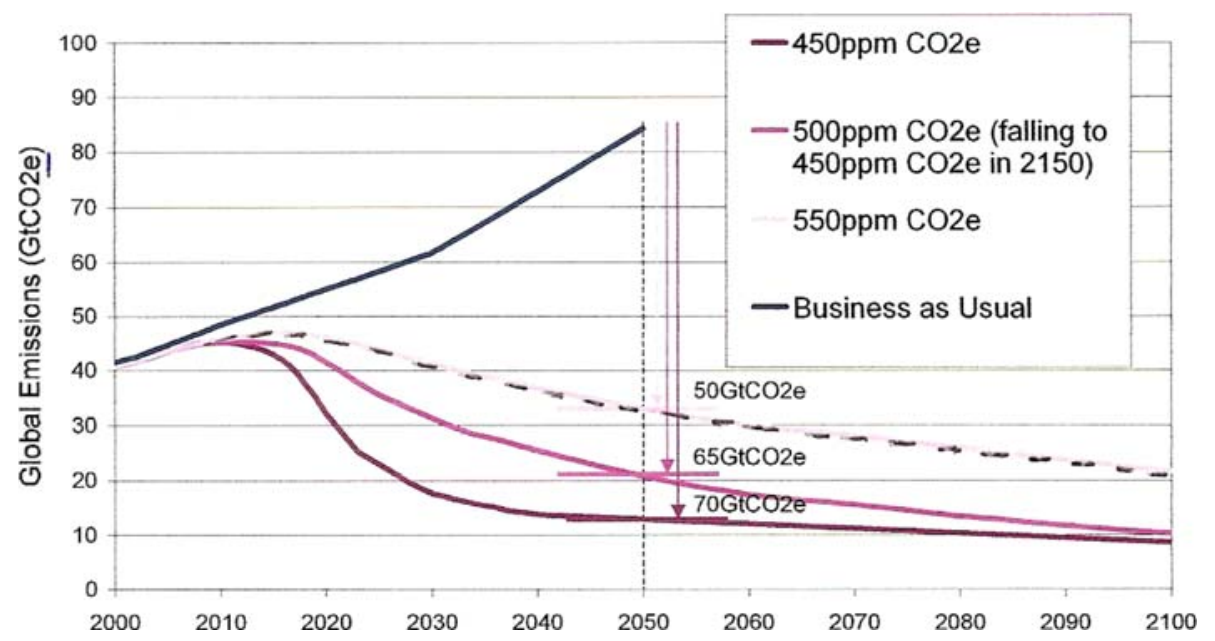

Fig. 1 Greenhouse gas emission scenarios (2000-2100) consistent with different levels of global; warming. Source: Stern (2006)

Table 1 The mitigation challenge

\begin{tabular}{|c|c|c|c|c|c|}
\hline & \multicolumn{5}{|c|}{$\begin{array}{l}\text { Population } \times \text { Av. Income } \times \text { Energy intensity } \times \text { Fuel mix }=\text { Carbon emissions } \\
\text { or } \\
\text { Pop } \times \text { GDP/Pop } \times \text { E/GDP } \times \text { C/E }=\mathrm{C}\end{array}$} \\
\hline & $\begin{array}{l}\text { Pop } \\
\text { bns }\end{array}$ & $\begin{array}{l}\text { GDP/pop } \\
\text { PPP\$ }\end{array}$ & $\begin{array}{l}\text { E/GDP } \\
\mathrm{MJ} / \$\end{array}$ & $\begin{array}{l}\mathrm{C} / \mathrm{E} \\
\mathrm{KgC} / \mathrm{GJ}\end{array}$ & $\begin{array}{l}\mathrm{C} \\
\mathrm{GtC}\end{array}$ \\
\hline 2030 & 6.42 & 6,541 & 12.1 & 14.8 & 7.5 \\
\hline 2100 & 11.3 & 29,730 & $\begin{array}{l}4.5 \\
\sim 60\end{array}$ & 13.4 & 20.4 \\
\hline $21002^{\circ} \mathrm{C}$ & $9-11$ & $25-30 \mathrm{~K}$ & To be 7 & & 2.0 \\
\hline
\end{tabular}

within the $2^{\circ} \mathrm{C}$ maximum for the decades ahead would be the nasty way: reducing average incomes (or even population - if that were at all feasible). Failing these too, the option left would be to give up on the $2^{\circ} \mathrm{C}$ cap. So, the world is caught between a deep blue sea (deeper than at present) and the devil of unwanted technologies or dwindling incomes.

Speaking of dwindling, the longer economies wait with starting to mitigate, the more the right hand parts of the curves of Fig. 1 will be pushed down, towards the horizontal axis. The carbon space will then become compressed - and nearly vanish. Secondly, as the world population continues to grow (which it is likely to do at least till 2050), then the per capita carbon space will shrink. There is a third reason to be concerned over the amount of carbon space left: the curves that I show here relate to an assumed desire to avoid certain effects of warming - but given that recent studies have given rise to the fear that the adverse effects are setting in earlier than expected and faster, some have argued that the cap should be put at lower levels than $2^{\circ}$. That might become economically very costly and possibly technically unfeasible.

So far the analysis has been at the level of one world - the planet as a whole and its human population as a homogeneous entity. Neither reduction is appropriate; here I will bring in at 
least a bit of social sophistication: we live in an unequal world and that is also visible in the area of climate change.

\section{Sharing the Carbon Space}

Thinking in terms of EUS evokes the question of who has access to this space, or how this access is distributed or shared.

There are several categories of potential users: (a) the present generation of humans, (b) future generations, and (c) non-human biodiversity. We will focus on the first two. Obviously, sustainable development requires development where it is needed, before moral obligations to future generations can be considered. There can be no ecology without equity-yet: neither can there be equity without ecology (Sachs 2002). A strict cap on warming would keep at bay a number of things the world would not like, such as several meters of sea level rise, drying up rivers in South Asia and China, further droughts in Africa, etcetera. Effectively, such a cap would potentially safeguard the interests of future generations. So in what follows I shall restrict myself to sharing between developed and developing countries.

Discussions on sharing the environmental space date back to the preparation for the UN Conference on Environment and Development (UNCED), during which it was argued that developed countries should 'make space for the South' and 'share Environmental Space', to allow for the development of poor countries (Hadj-Sadok 1992; Opschoor 1992, 1993; Khor 1997). Echoes of these early calls could be heard in the South Centre (2007) plea (see above).

Much of the once existing Carbon space has been taken in by economic development in the industrialised part of the world. This still to a large degree influences current emission patterns (though less so now than in, say, 1990, with China and India moving up rapidly on lists of emitters (see the first columns of Table 2 below). The question is, what would be a fair or equitable way of sharing the remaining $\mathrm{C}$-space. Let us look at the carbon space again and consider envisaged ways to share it (Fig. 2).

Here we see the world moving along a pathway towards a very carbon-poor future (by about 2050) and we see a path for the rich countries towards that. Global emissions drop by 80\% (against the 1990 values). Emissions of the developed countries drops even more than the global average: with $90 \%$. Even if these heroic assumptions on emissions reduction are met, they leave the world with a problem: the space remaining for developing countries is not big enough to allow them to grow even at a constant level of emissions: if they did, then in 2050 global emissions would be at $6.4 \mathrm{Gt}$, 10 times as high as would be consistent with staying below the $2^{\circ}$ cap. The effective space under the $2^{\circ}$ cap is rather small-and it is to be shared by quite a lot of people. Roughly speaking, the developing countries this solution would amount to a reduction with $60 \%$ below their 2000 level. This is much less than the $90 \%$ reduction in the North but yet: per capita emissions in the North would be almost 2.7 times those of a person in the developing countries. Implicit in the statement by the South Centre is the request to share in a much fairer way, the overall carbon space. The question is: how, on what principles and with what effects.

The first ones to address these issues were Agarwal and Narain (1991). They estimated the repercussions of equitably sharing between countries a given global Carbon "budget" on an equal per person basis. Their total emissions per annum were constrained to not exceed a level that can be absorbed by the environment (the "Carbon sink", estimated at 17,500 Mt of $\mathrm{CO}_{2}$ ). On that basis they estimated what countries' permissible emissions were and compared these with their actual emissions. Excess emissions (net emissions to the atmosphere, estimated at some $13,500 \mathrm{mT}$ ) were to be punished with a tax and surplus permissible emissions could be 


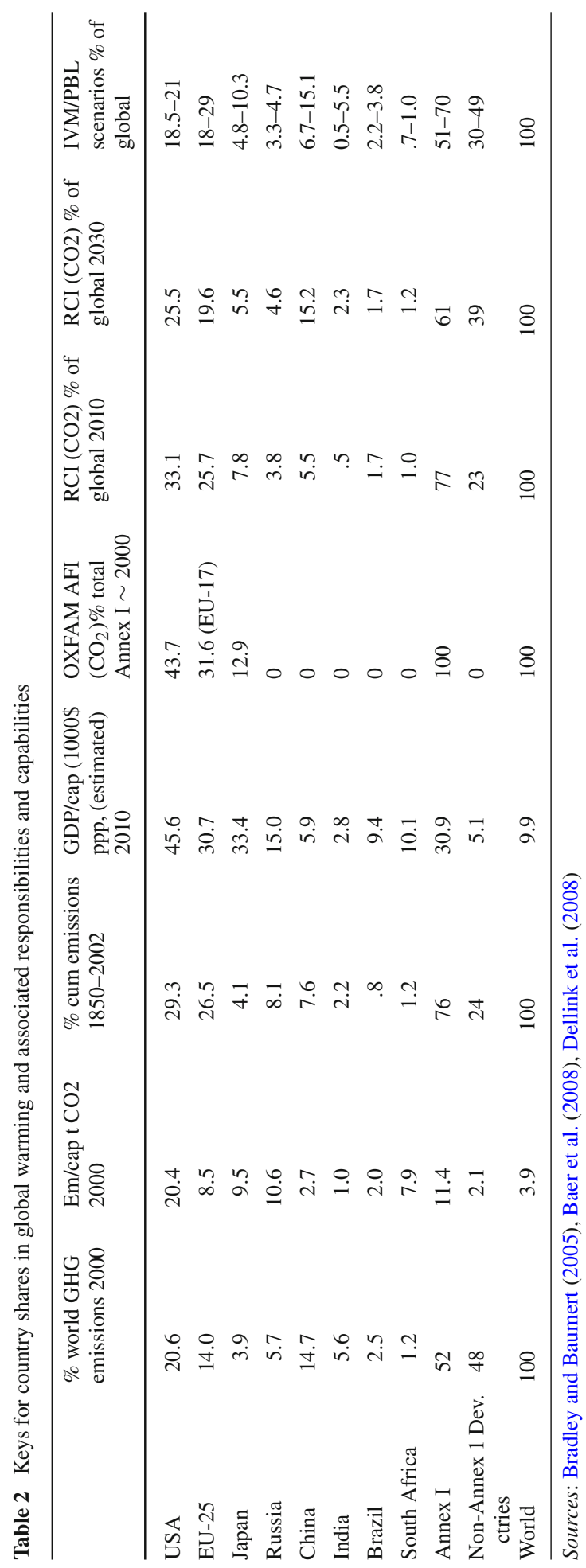




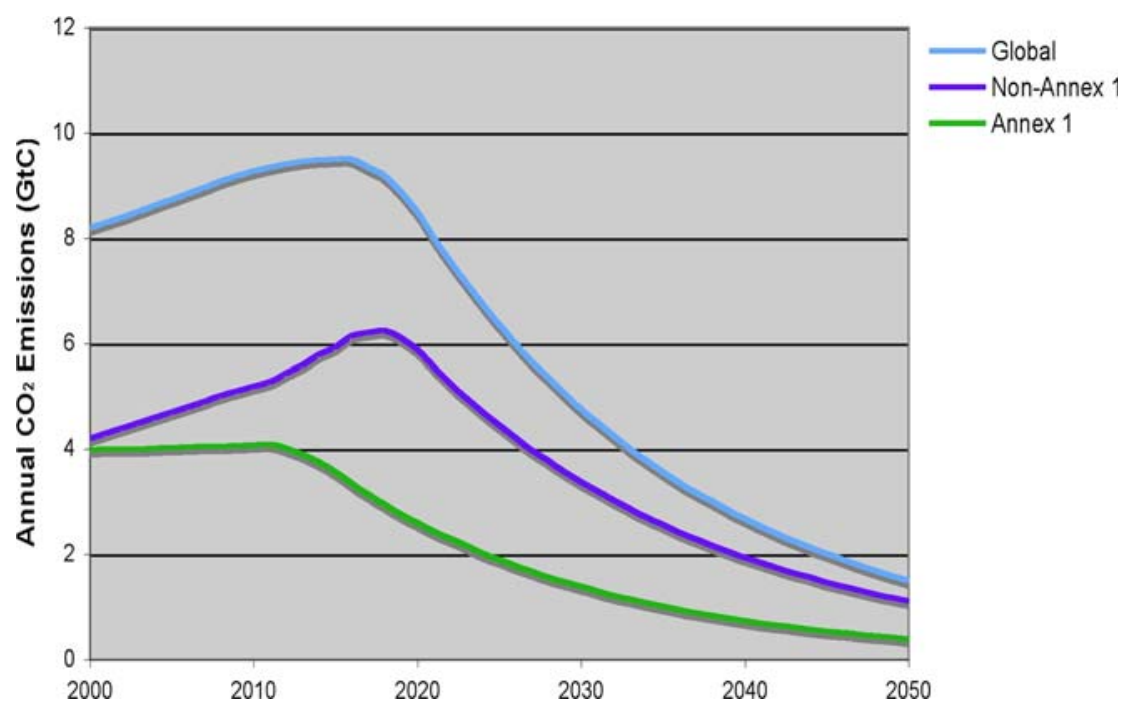

Fig. 2 Global carbon space $\left(2^{\circ}\right)$ sharing between annex I and non-annex I countries (2000-2050). Source: Baer et al. (2008)

traded to those in need of such permits. ${ }^{6}$ At the same time my own research council worked on a whole set of EUS-subspaces including one for $\mathrm{CO}_{2}$-emissions (Weterings and Opschoor 1992). Based on pre-UNCED data we estimated that global emissions in 2040 would have to be reduced by $80 \%$ compared to what they would otherwise be, and that in the remaining carbon space $15 \%$ should be the share of the North (rather than $75 \%$ ), and $85 \%$ should go to the developing countries, if we accepted equal per capita emissions as a standard. Work like that has been going on since then and the numbers were refined and up-dated. It is interesting to see that figures now presented to the negotiations toward the new global climate agreement still suggest the need of reductions of $80 \%$ or even more in 2050.

Equal per capita entitlements seem one more or less 'natural' moral principle. Agarwal and Narain (1998) discern essentially 2 ways of elaborating this: (i) equal shares in a global carbon budget (e.g. the global carbon sink, as in their 1991 application), (ii) a long term converging per capita emissions target consistent with global emissions keeping warming below an agreed cap. Of course, there are other ways of cutting the emissions pie than egalitarian ones. Countries may claim or be allocated shares based on their current levels of emissions. This is done in practice when introducing emissions trading schemes, and is called 'grandfathering'. Note that the second proposal by Agarwal and Narain allows starting with grandfathering to end up with equal per capita emission shares after some period in which convergence is to occur. This may be an appealing idea allowing for some flexibility in the initial stages — but still it may not be easy to achieve. ${ }^{7}$

\footnotetext{
6 Similar schemes were put forward by other CSOs; e.g. WCC 2000 proposed a Global Atmospheric Commons Fund based on equal per capita emissions under a sustainable level of emissions. Countries using in excess of the permitted emission level would pay a use penalty from which developing countries should be assisted in moving towards a carbon-free or-poor economy.

7 Based on econometric analysis Barassi et al. (2008) show that per capita $\mathrm{CO}_{2}$ emissions among OECD countries in 1950-2002 showed no convergence. If it did not happen there, it is likely to meet with more hurdles if we consider global convergence. As the authors say: tackling these political hurdles “... may impose a burden of significant adjustment costs due to the required re-distribution of emissions" (ibid: 134).
} 
A system based on equal (or fair) per capita entitlements within a space that is actually sustainable ecologically, is the most fundamental—and in the long run perhaps the most socially acceptable — approach. There are difficulties associated with it, though, ${ }^{8}$ and it may not be the most suitable way of bringing equity considerations to bear on ways of dealing with climate or climate-related problems. Equity has different dimensions or can be pursued following different approaches. Ashton and Wang (2003) list: (i) Responsibility, (ii) Capacity to act, (iii) Equal entitlements, (iv) "Basic needs" (or: solidarity), and (v) Comparable effort. For practical purposes (iv) can be seen as another element next to (iii) in a category "provisions sharing", and (v) can be linked with (ii). So essentially we are left with (in addition to sharing): responsibility and capacity—categories that we shall meet in the next section when we address equity in relation to burden sharing.

\section{Sharing the Burdens of Mitigation and Adaptation}

Entitlements to emissions are one way of looking at sharing emissions, but given the need to fit all emitters into the shrinking carbon space it is also interesting to step through the looking glass and consider responsibilities for staying within it - the mirror image of entitlements. This is important when the concern is how to deal internationally with a threat to humanity like climate change. Then the question becomes: how to share the burden of ensuring that the worlds' economies stay within the carbon space.

Art. 3 of UNFCCC stipulates the following principle:

The Parties should protect the climate system for the benefit of present and future generations of humankind, on the basis of equity and in accordance with their common but differentiated responsibilities and respective capabilities.

This principle is the cornerstone of the Convention. ${ }^{9}$ Two broad normative notions are introduced here: that of responsibility (e.g. based on historical roles in causing global warming, or on the notion that the polluter should pay, for mitigation of for damage or adaptation) and capability (based on the observation that the economically more advanced countries can more easily carry the burden of mitigating climate change). Responsibilities could be measured by emissions (of GHGs, or of particular ones such as $\mathrm{CO}_{2}$ ) and parameters capturing land use change. Emissions could be measured by taking the actual per annum values or by taking cumulated emissions; in the latter case different staring (and end) dates could be considered. Emissions may also be measured as excess emissions above some entitlement (e.g. the share in the carbon sink, cf Agarwal and Narain 1991), or as emissions for consumption beyond basic needs or some other "development threshold"- related entitlement (Baer et al. 2008). Capabilities can be measured in various way too, but it is fairly common to take some measure of 'capacity to pay' (as in the IVM/PBL-"scenarios", Dellink et al. 2008), i.e. per

\footnotetext{
8 Equal entitlements has many problems. If applied, e.g. through public ownership and access, delivery in practice may easily deviate from intended access. And: why would this resource be shared equitably if this is not done in case of other resources? Another issue is: do entitlements not have to vary if we want, for reasons of fairness, to differentiate according to variations in domestic (or even regional/local) circumstances? And, last but not least: how can larger de facto per capita emitters be induced to accept such schemes?

9 Other principles are: (i) full consideration to the specific needs and special circumstances of developing country Parties, especially those that are particularly vulnerable to the adverse effects of climate change; (ii) the precautionary principle: where there are threats of serious or irreversible damage, lack of full scientific certainty should not be used as a reason for postponing such measures; (iii) the right and duty to promote sustainable development: (iv) the duty to cooperate to promote a supportive and open international economic system that would lead to sustainable economic growth and development.
} 
capita income or GDP, or per capita income beyond a certain threshold (as in the RC-index proposed by Baer et al. 2008). "Capabilities" may also be based on the Human Development Index (as in OXFAM's Adaptation Financing Index-OXFAM 2007). Table 2 summarises country shares in global warming responsibilities and capabilities.

Before detailing the calculations behind Table 2, let me articulate what the table conveys. These are all possible keys to attributing responsibilities for burden sharing. Apart from the OXFAM AFI they show a range of calculated shares for Annex I countries, from 52-77\%, the balance being put on the plates of developing countries. Giving responsibility to Annex I countries only, would, of course bring the total for these countries up to $100 \%$. Secondly, it makes a large difference whether one looks at current emission levels (per capita, or total) or at cumulative emissions. Thirdly, weighing contributions to emissions by income measures makes a difference as well, especially when this is done in a progressive way-e.g. by absolving people or countries with low incomes (last 3 columns). Of course if we look at countries along a sliding scale sensitive to their long term economic growth and expected emissions ( $\mathrm{RCI} / 2030$ versus RCI/2010), then countries like China and India are debited much more than when static status quo approaches were followed.

Observations like these go some way in explaining positions taken at conference tables where climate policies are discussed. It is in the interest of developing countries to prevent that they are saddled with commitments beyond what the Bali Action plan calls for (action that is in these countries' own interest quite apart from the climate issue). It is in their interest that they emphasise the logic of 'historical legacy' in defence of responsibilities falling largely on developed countries — which, as a matter of course, take opposite positions. And in fact these discussions are not irrelevant from a financial or economic perspective. The need for new and additional means for climate-related action in developing countries alone is around a level of roughly $\$ 200$ billion per year for mitigation and $\$ 70$ (or 50-100) billion for adaptation. If context is needed to understand the significance of these figures: the total amount of ODA disbursed by the same countries that are assumed to cough up these \$200-300 billions is currently at \$100-120 billion!

Differences in outcomes reflect differences in assumptions or other choices made in the application of responsibility/capability criteria. IVM/PBL (Dellink et al. 2008) calculate the repercussions of attributing responsibilities in terms of emissions (measured in a variety of ways) weighted by capacity to pay (measured in relation to GDP or according to UN-contributions) in seven 'scenarios'. As can be expected, the results are dependent on the assumptions made and the indicators chosen. The differences can be large, especially when allotting shares is done based on a progressive scale; much of the difference vanishes when proportionality with GDP is the point of departure. Baer et al. (2008) base their RCIs on calculations starting from personal income levels. They propose that below a certain treshold emissions are related to necessities and that to ensure staying within warming caps households below that threshold should be exempted from having to contribute to fighting global warming (they suggest a level of PPP\$7,500 pppa, and estimate this would protect some $70 \%$ of the world population). ${ }^{10}$ Thus, income distribution comes in and the wealthy in developing countries are to contribute to mitigation and adaptation costs and investments as well as developed countries. For responsibility they take countries' cumulative emissions since 1990 excluding emissions corresponding with sub-threshold consumption. These two measures they combine into one "Responsibility-Capacity Index (RCI)". The RCI has a dynamic variant using projections (of GDP, population, cumulative emissions) leading to evolving values for the

10 In their 1991 paper Agarwal and Narain distinguished "survival emissions" (emissions related to meeting basic needs) from "luxury emissions" (emissions related to consumption beyond basic needs). Baer et al operationalise this idea. 
index as the underlying values change. In its static form, RCI is similar to OXFAM's AFI (OXFAM 2007), which used emissions for responsibility $\left(\mathrm{CO}_{2}\right.$, av over 1992-2003 beyond 2 tonnes pppa), and capability as measured by the 2004 UNDP Human Development Index (countries with HDI >.9 only).

A sensitivity analysis on the RCI showed that by 2030 all runs of their model do put global emissions down to 50\% form the 1990 values. In developing countries emissions will double compared with 1990, but they will be about half of the BaU-values for those countries. Least Developed countries would be able to grow even more: to emissions about 3 times their 1990 forerunners. Secondly, bringing the threshold down from US\$(PPP) 7,500 to 5,000 will make non-Annex I countries have to further reduce emissions by some 5\%, which eases pressures on Annex I countries by over $25 \%$. This will also impact on financial contributions per person: it would bring that down globally by some $20 \%$ and even more in Non-Annex I countries, especially low income countries and LDCs.

\section{Differentiation}

We saw that the carbon space consistent with below $2^{\circ}$ warming is dwindling rapidly as we move closer to 2050. If the world is to stay within it, then developed economies- the wealthiest sources of greenhouse gases should quickly and deeply engage in mitigation. Figure 2 suggests that even if Annex I countries were to have stopped all $\mathrm{CO}_{2}$ emissions by 2050, then developing countries, if they kept their emissions at current levels, would still emit over 5 $\mathrm{GtC}$, which would bring global $\mathrm{CO} 2$-emissions to levels 2.5 times above the allowed $\mathrm{C}$-space. Sooner rather than later all the worlds largest sources need to mitigate- whether wealthy or not. This is understood (see the BAP, UNFCCC 2007) — but the extent to which and the conditions under which are highly contested. The battleground has a name: 'differentiation'.

To allocate responsibilities while taking into account capabilities, UNFCCC distinguishes ('differentiates') between developing countries (non-Annex I) and developed ones (Annex I; the latter further distinguished into the OECD countries -Annex II- and other). These categories reflect national conditions as prevailing in 1992 (cf Art. 31). The BAP, when dealing with mitigation, stipulates that all developed country parties must consider mitigation commitments, with comparability of effort to be ensured by taking into account differences in their national circumstances. Developing countries are to consider nationally appropriate mitigation actions, in the context of sustainable development and supported and enabled by technology, financing and capacity building (BAP Art 1.b, UNFCCC 2007b).

Some developed (Annex I) countries have claimed that many developing countries must also consider committing to targets for reducing emissions or improving energy efficiency, and that some might even "graduate" into an up-dated Annex I. ${ }^{11}$ A redefinition of "developed" and "developing countries" under BAP was proposed, and criteria for differentiation suggested, including HDI, GDP (total and per capita) and share of world emissions. This further differentiation (beyond Annex I/Non-Annex I) thus seeks to reflect changing and differing national circumstances across all countries-including developing ones- to ensure equitable CC-mitigation (see e.g. Ott et al. 2004; Hohne et al. 2008; Karousis et al. 2008; OXFAM 2008). However, the developing countries generally reject this-essentially on the ground that developed countries are historically responsible for most of the warming and that they should therefore be the only ones to undertake binding commitments to address its

11 For a substantiation of this, see, e.g. Ott et al. (2004) and Hohne et al. (2008). 
causes. ${ }^{12}$ It may be understandable that non-Annex I countries object to their group being split up in divisions at the risk of losing influence in international climate negotiations. At the same time, in my opinion it is desirable (and in fact inevitable) to look for options to enable mitigation efforts to be shared between those countries that are capable to undertake them and historically responsible (i.e. Annex I countries) and those who, related to their contributions to current and future commitment, show a potential to mitigate (the phrase as well as the proposal is due to: Ott et al. 2004) since their emissions are significant in the global total. The South Centre $(2007,13)$ argues that: “... a possible arrangement could be one where developed countries are required to cut their GHG emissions by at least $95 \%$ below 2000 levels by 2050. Developing countries ... especially ... those whose emissions already, or will in the near future, contribute significantly to atmospheric GHG concentrations-should also engage by ensuring that, conditioned on the provision of appropriate technology transfer and adequate technical and financial support from developed countries, their voluntary national climate change plans aim for GHG emissions reductions ... in ways and levels that are appropriate to their development needs and priorities" (the italics are mine). I would applaud that if also the footnote to this statement applies (ibid.): "A differentiated approach that takes into account the specific development conditions and requirements of individual developing countries, and which promotes the participation of the developed and developing countries that contribute the most to total GHG emissions in a global agreement to reduce GHG emissions would seem to be the most feasible."

Different schemes have been put forward to elaborate this (Ott et al. 2004; Hohne et al. 2008; Baer et al. 2008). ${ }^{13}$ Each of these approaches suggests a different ranking of countries; Karousis et al. (2008) show that those various measures are not correlated between themselves. No single index captures all of these considerations. If these single indexes are amalgamated into reasonable composite indicators, then much more correlation shows up; and there is much more consistency between associated country rankings. This suggests that through negotiating about such more complex measures of potential, responsibility and capability, agreements might be possible.

But the main point of this section is, that the global carbon space has dwindled to such an extent that staying within the remainder of it can only be done if substantial mitigation occurs in developing countries, and that this requires not only convincing and far reaching a

\footnotetext{
12 The Hoikaido Toyako G8-Summit (July 2008) established that the G-8 agreed to implement ambitious mid-term mitigation goals and welcomed the proposals by MDBs and donors to establish funds in support of efforts of developing countries in investing in climate. The "major developing economies" (Brazil, China, India, Indonesia, Korea, Mexico, South Africa) approved this G-8 approach and agreed to pursue “...nationally appropriate mitigation actions, supported and enabled by technology, financing and capacity-building, with a view to achieving a deviation from business as usual emissions" (Hokkaido Toyota Summit 2008). This seems to go slightly beyond the mere recognisiton of the commitment to undertake NAMAs. At least one of these, RSA, is committed to declining its emissions significantly after 2030-2035 and is ready to do more if and when international support is forthcoming (according to its statement at CoP14 in Poznan, 2008).

13 Ott et al. (2004) elaborated a possible scheme for this (with different mitigation menus) for the following 'groups of countries': Annex II, Annex I but not Annex II, NICs (newly industrialized countries), RIDCs (rapidly industrialized countries), Other DCs, and LDCs. Hohne et al. (2008) detail this in terms of specific countries' commitments below 'business as usual' for 6 NICs and RIDCs in several 'scenarios': a "no regret scenario" (with reduction options at zero or negative costs), a "co-benefit scenario" (with positive costs but compensated by other societal benefits in the mitigating country) and an "ambitious scenario" (with uncompensated net costs, unless through financial support by outside donors). Most countries could contribute with reductions below $\mathrm{BaU}$ at levels from $15 \%$ up to $40 \%$, with financial support or technical assistance. As we saw, Baer et al. (2008) have operationalised this in a combined responsibility/capability index excluding emissions due to meeting basic needs (liberally defined), in a way that does indeed bring in rapidly industrializing countries according to their potentials, and that also takes into account historical 'legacy'-considerations (i.e.: it is based on cumulative emissions) (see Table 2).
} 
priori commitments by the industrialised countries to engage in mitigation but also a manifest and convincing readiness to help developing countries (financially, technologically) to also engage in mitigation at the necessary levels. This could help overcome the trust gap mentioned before as one of the main hurdles on the way to a global agreement. It also is in the interest of industrialised countries to engage in this.

\section{Climate Change and Making Development More Sustainable}

Development and poverty eradication require economic growth. Carbon-based growth is no longer an option. How can the world (North and South) de-carbonise in a fair and effective way and stay within an acceptable carbon space? We have seen that such a V-turn may be technically and economically feasible if the political will were there.

According to IPCC $(2007,21)$ : "making development more sustainable by changing development paths can make a major contribution to climate change mitigation...". It points at synergies that would lead to benefits in the climate domain as well as in the development domain - traditional, or sustainable development. It is obvious that changes in investment, production and consumption patterns are required.

Major impulses towards such changes are expected from bringing external social costs (including costs to future generations) into decision-making by major polluters through raising prices of energy and introducing Carbon pricing (e.g. by creating markets for emission permits and similar devices). Such institutional change is envisaged as part of the concept of sustainable development (see definition above). Harnessing market forces towards mitigation may also generate adverse spinoffs in developing countries (trade effects, negative distributional effects, etc. Moreover, if warming is to be halted, then mitigation is to occur in developing countries beyond what they might undertake in view of net benefits to their own populations. And finally, we have seen that technological innovation is to occur on a large scale to enable adequate mitigation. These elements combined call for a policy-driven approach also in developing countries, with a strong component of North-South co-operation, including a strong investment programme, to create the necessary institutional capacities, to stimulate carbon-free innovation and green investment, (cf CDP 2007). Much of the finance needed for such investment programmes may be harvested from carbon markets or emission permits markets generally, but not all of it.

This is the top-down view. For both developing and developed countries another observation by IPCC is also highly pertinent: "national circumstances and the strengths of institutions determine how development policies impact GHG emissions. Changes in development paths emerge from the interactions of public and private decision processes involving government, business and civil society". So the top-down approach must and should be complemented by a bottom-up one towards making development more sustainable. That in itself-if done in a 'climate resilient' way-would primarily enhance effective adaptation, and then also deal with mitigation. As far as mitigation is concerned, one very promising example is the emergence of so-called "global action networks" operating in a collective action perspective (Glasbergen et al. 2007; Ostrom 1990). Indeed, a diversity of institutional change will be required to make development, across the globe, more sustainable (cf. e.g. Dolsak and Ostrom 2003) and this must go far beyond the involvement of market forces alone-critical though their contribution may be. It is here that I refer back to my earlier observations of such forces in the global economy, related to their lack of embeddedness, short-sightedness, their tendency to cost-shifting and uncritical orientation on forces of economic growth and technical innovation. What is needed to effectively respond to these critiques is the emergence of political will and capability to manage globalisation and its agents towards the satisfaction of 
common needs and the provision of global public goods-supplementary to what the market may be made to deliver. And what is even more complex, making development sustainable and climate proof in this way will require changes in prevailing cultures in relation to society-biosphere relationships, human welfare and the role in it of material consumption, and a new global ethos based on accountability, solidarity and care.

In terms of proposals to work towards such lofty aims, what do we see of this when we look around us? In and around the UN system initiatives for green development or green climate and energy related development schemes abound.

For instance, UNEP's "Green Economy Initiative" and its subsequent plan for a Global Green New Deal (UNEP 2009) want to gear the world's readiness to take anti-cyclical action in the face of the economic crisis towards structural transformations in technology, production and consumption, and resource management. UNEP too recognises market failures and rightly adds the failure of governments to intelligently and prudently manage and focus markets. The plan aims at: (i) reviving the global economy and saving and creating jobs; (ii) reducing carbon-dependency and ecosystem degradation; (iii) advance sustainable and inclusive growth, achievement of the MDGs and the end of extreme poverty by 2015 . Regarding employment generation through "green" jobs, in the domain of renewable energy alone UNEP 2008 envisages the possibility of over 2 million new jobs. UNEP suggests this could be done by an injection valued at $1 \%$ of global GDP, or about 1/4th of what is being made available for fiscal stimulus). The plan is sectorally detailed, has the usual institutional proposals for incorporating externalities in prices (e.g. through taxes) and harnessing of market forces, and adds to that an "international policy architecture" providing a framework for and co-ordination of the transition towards a more sustainable economic system. The initiative builds on the earlier Green Jobs Initiative by UNEP, ILO and non-governmental organisations like the International Trades Union Confederation.

UN-DESA (the Department of Economic and Social Affairs) falls in line with this by proposing a Global New Deal for Sustainable Development" as part of a broader counter-cyclical response to the current economic crisis (DESA 2009). It adds to the UNEP proposal a more manifest focus on domestic fiscal stimulus in developing countries, and a more explicit focus on poor and vulnerable groups. Here too a number of specific activities are outlined.

Outside the UN similar ideas have been floated (e.g. Obama's "Green New Deal" for the USA and the calls for more inclusive and even green recovery plans I mentioned before) The Potsdam Institute/LSE proposal for global green recovery (Edenhofer and Stern 2009) to the G20 as they discussed the economic crisis. That plan (in which the economic crisis and the climate crisis are explicitly linked) has much less of a development focus than the ones mentioned above, focuses on energy technologies and infrastructure, clean technology markets and asks for co-ordinated efforts by the G20. At the time of writing this address, the G20 had not responded to this-despite the earlier noises made by it and by relevant political actors associated with it, when the economic crisis was first discussed by the G20 in November 2008. Indeed, it is important to avoid recovery in the direction of: back to the usual. Certainly, the crisis and the efforts to address it provide an opportunity to change course. The word needs to know where it wants to be if it is to decide which direction to take and it is right to articulate sustainable, equitable, human development orientations. But we need to develop a robustness necessary for turning these tactics into embedded national and international strategies if they are to be sustained in the period after the recession is over.

A more structural and strategic approach is suggested by the UN Committee for Development Policy (CDP 2007, 2009) for an innovation-cum-investment oriented approach to dealing with climate changing emissions. As a development strategy it is to serve and help meet the needs of the present generation, by expanding options for improving livelihoods 
and wellbeing. As a sustainable development strategy it is to ensure that this meeting of present needs does not go at the expense of options and possibilities for welfare generation in future-both for people alive today and for at least the next 2 or 3 generations. And as a climate-focused strategy within the perspective of sustainable development, it is to ensure that emissions will be cut. Most of the world's power plant construction over the next 40 years and most of the world's primary energy consumption growth will take place in developing countries. Where new plants are constructed they must be made is carbon free as possible: plant construction "freezes" ("locks in") carbon-efficiencies for their entire life span-typically 30 to 40 years. The so-called 'incremental costs' of going for carbon-free or carbon-poor alternatives in energy investment are to be funded with international support.

Incentives need to be identified and provided for economic growth and development along pathways that are ecologically and socially sustainable and are climate neutral and climate change-resilient. The strategy should boost efforts in research and development of new technologies and alternative, renewable and cleaner energy sources that are appropriate in a developing countries' context and in a sustainable development perspective, and capacity building for mitigation as well as adaptation, and development-oriented research and policy articulation. An innovation and investment-oriented strategy like this could generate opportunities for economic activities on the international market.

This strategy amounts to a more development oriented alternative to Sachs (2008) 'economics for a crowded planet' aiming at tackling, through global public investments towards sustainable development, a portfolio of risks like climate change, extreme poverty biodiversity loss, population growth (ibid: p. 11). He puts forward a menu of environment friendly and energy saving innovation, strategies to escape the poverty trap, and development - thereby proposing a growth/technology-oriented way out. In the climate/energy domain he too proposes developing market based incentives e.g. through trading carbon (or GHG) emission permits, and huge R\&D-efforts, with additional funding to be provided by developed countries. His plan for global sustainable development also suggests public interventions in the areas of support for the destitute, key infrastructure, social insurance, research and development, stewardship over natural resources and generally support a globalisation based on the idea of a social welfare model. Sachs' analysis is based on an acknowledgement of market failure in globalisation as we know it, and of the need for policy intervention to guard the interests of future generations and other marginalised stakeholders. Yet, his analysis (as well as that of most others mentioned above) does not contain serious and critical analysis of the underlying institutional structures and driving forces. When it comes to curbing climate change and unsustainability in the global market-based) economy they remain largely investment/technology/growth oriented and at best call for co-ordination between international agents, in a top-down perspective, without giving much attention to the complementary bottom-up process, the need for countervailance in power relations, the need for cultural and ideological change in the "global North" (wherever that manifests itself). It is here that I hope ISS and like-minded social science institutes will join forces and provide embedded, accountable, responsive institutional options that can be considered for incorporation in climate strategies once the world has decided it is really going to tackle climate change.

\section{Some Final Observations}

In concluding this address, let me summarise some main pints and look ahead a little.

Climate change is perhaps the most burning (excusez le mot) issue amongst the global environmental concerns and a prominent one on the world development agenda. The multilateral 
community must develop a capability and a readiness to prevent dangerous human-made warming within a time frame that allows enable economic development to proceed in a sustainable, climate change-resilient and climate-proof manner. Scientific evidence suggest this to mean a cap on warming at $2^{\circ} \mathrm{C}$ or less, by 2100 . This then defines a 'carbon space'. Claims on that space are growing rapidly and threaten to move the world beyond it-in unsafe danger zones-ecologically, socio-economically, technically.

Deep cuts in emissions of GHGs are required to stay within the carbon space. If by 2100 the world is to be under the $2^{\circ}$-cap and if average incomes and population levels are to be according to expectations, then carbon per unit of GDP is to be reduced by almost $90 \%$ globally. In fact, the global carbon space has dwindled to such an extent that staying within it can only be done if substantial mitigation occurs in developing countries-however, one must realise that they were not prime responsibility for this dwindling so far nor do they have the capabilities (financially, technologically) to take on mitigation commitments. Compounding these concerns, the carbon space needs to be shared in a way that is considered fair and this requires "convergence" of currently widely unequal per capita emissions.

Some of the factors accounting for the present lack of progress in achieving a climate agreement are rooted in a deep deficit of trust between developed and developing countries. This deficit must be overcome if an effective and adequate compact is to be achieved. That implies that OECD countries take a convincing lead in emissions reduction, share their knowledge and other capabilities in this field with developing countries, co-develop new technologies and management regimes for energy use, and co-fund efforts especially where these lead to incremental costs and incremental efforts. The finance required for this is huge-though still a small fraction of World (or even OECD) Product. Such funds are not easily raised, even if future new markets for emission permits other mechanisms might be capable of generating large portions of it. Consensus of what, in this context, equitable burden sharing would mean, is not easily achieved - though not impossible. It requires agreement about criteria to apply_such as 'responsibility', 'capability' and 'potential' and how to quantify these. In the latter area alone, very wide-ranging outcomes have been found-though, again, agreement on such formulae is not inconceivable.

Green New Deals as proposed in the context of a widened response to the current economic crisis could become a beginning of a fundamental shift towards a decarbonised global economy. So far, though, such green new deals have not left their drawing board. Moreover, they would represent a beginning only, to be sustained well beyond recession recovery periods. This complex global threat calls for an international response ensuring the availability of sufficient carbon space to develop. The world, in all its regions, needs to avoid the pitfalls of carbon-dependent economic growth and find alternative, more sustainable development trajectories. That is an issue of changing patterns and pathways of investment and innovation, as well as of production and consumption. Concerns to do with equity as well as sustainability must be incorporated and integrated into coherent transitory strategies. Conceptually, this is clear and many plans for this have been elaborated - though not yet adopted in tangible development planning. Perhaps they need further work: researching and developing. But their getting implemented also need a change in political will.

I conclude with an observation rooted in political economy/institutional economics: greater global equity as well as ecological sustainability can be achieved only by internationally co-ordinated and implemented policies improving the endowments of countries and people, and capable of dealing with the relevant world market imperfections. The institutional repercussions of this are yet to be elaborated; the end of radical neo-liberalism may provide a policy space for this. 
Open Access This article is distributed under the terms of the Creative Commons Attribution Noncommercial License which permits any noncommercial use, distribution, and reproduction in any medium, provided the original author(s) and source are credited.

\section{References}

Agarwal A, Narain S (1991) Global warming in an unequal world: a case of environmental colonialism. Centre Sci Environ, New Delhi

Agarwal A, Narain S (1998) The atmospheric rights of all people on earth. Centre Sci Environ, New Delhi

Altvater E (2009) Postneoliberalism or postcapitalism: the failure of neoliberalism in the financial market crisis. Development Dialogue (51):73-89

Anderson JO, Lindroth M (2001) Ecologically unsustainable trade. Ecol Econ 37:113-122

Ashton J, Wang X (2003) Equity and climate: in principle and practice. Working draft, Beyond Kyoto Series, Pew Center on Global Climate Change

Baer P, Athanasiou T, Karth S, Kemp-Benedict E (2008) The greenhouse development rights framework: the right to development in a constrained world. Heinrich Boll Foundation, Berlin

Barassi MR, Cole MA, Elliott RJR (2008) Stochastic divergence or convergence of per capita carbon dioxide emissions: re-examining the evidence. Environ Resour Econ 40:121-137

Bierbaum et al (2007) Confronting climate change: avoiding the unmanageable and managing the unavoidable, a new report prepared by the scientific expert group report on climate change and sustainable development for the United Nations Department of Economic and Social Affairs

Bradley R, Baumert K (eds) (2005) Navigating the numbers: greenhouse gas data and international climate policy. WRI, at http://www.wri.org/climate/pubs_description.cfm?pid=4093

CDP (UN Committee for Development Policy) (2007) The international development agenda and the climate change challenge. UN, Department of Economic and Social Affairs, E.07.II.A.7, UN Publishing Section, New York

CDP (UN Committee for Development Policy) (2009) Achieving sustainable development in an age of climate change. UN, Department of Economic and Social Affairs, E.08.II.A.16, UN Publishing Section, New York

Dellink R et al (2008) Sharing the buren of adaptation financing: translating ethical principles into practical policy. Institute for Environmental Studies (IVM) Amsterdam/Neth Environmental Assessment Agency (PBL) Bilthoven (Neth); IVM Report No. R08/05

DESA (Department of Economic and Social Affairs) (2009) A global green new deal for sustainable development. UN-DESA Poliocy Brief No. 12

Dolsak N, Ostrom E (eds) (2003) The commons in the new millennium: changes and adaptation. MIT Press, Cambridge

Edenhofer O, Stern N (2009) Towards a global green recovery: recommendations for immediate G20 action. Report submitted to the G20 London Summit. Potsdam Institute for Climate Impact Research

den Elzen MGJ, Berk MM, Lucas P (2004) Simplified multi-stage and per capita convergence: an analysis of two climate regimes for differentiation of commitments. RIVM report 728001027/2004, RIVM (PBL) Bilthoven (Neth)

Glasbergen P, Bierman F, Mol APJ (eds) (2007) Partnerships, governance and sustainable development: reflections on theory and practice. Edward Elgar Publ, Cheltenham

Hadj-Sadok T (1992) Making space for the south. In:Opschoor JB (ed) Environment, economy and sustainable development. Wolters-Noordhoff Publ, Amsterdam, pp 143-149

Hohne N et al (2008) Proposals for contributions of emerging economies to the climate regime under the UNFCCC post 2012. Umweltbundesamt Research Report 36401 003, UBA-FB 001200. Climate Change 15/08,Bonn. See www.umweltdaten.de/publiktionen/fpdf-1/3658.pdf

IPCC (Intergovernmental Panel on Climate Change) (2007) Summary for policymakers of the synthesis report of the IPCC fourth assessment report

Karousis K, Guay B, Philibert C (2008) Differentiating counties in terms of mitigation commitments, actions and support. OECD COM/ENV/EPOC/IEA/SLT(2008)2

Khor M (1997) Globalisation undermining sustainable development? Earth Summit Plus 5 Briefing Document No. 3; from http://www.twnside.org.sg

MacGregor J, Chambwera M (eds) (2007) Room to move: ecological space and emissions equity. Sustainable development: opinion. IIED (International Institute for Environment and Development), London

Meinshausen M et al (2009) Greenhouse gas emission targets for limiting global warming. Nature 458: 1158-1162

Milanovic B (2005) Can we discern the effect of globalization on income distribution? Evidence from household surveys. World Bank Econ Rev 2005 19(1):21-44 
Ocampo JA, Vos R (eds) (2008) Uneven economic development. Zed Books in association with UN, New York

Opschoor JB (1987) Duurzaamheid en verandering: over Ecologische inpasbaarheid van Economische ontwikkelingen. Oratie, 41 pp, Amsterdam, VU Boekhandel/Uitgeverij

Opschoor JB (1992) Sustainable development, the Economic process and economic analysis. In: Opschoor JB (ed) Environment, economy and sustainable development. Wolters-Noordhoff Publ, Amsterdam, pp 25-53

Opschoor JB (1993) Reccession makes north renege on Aid. Down to Earth Science and Environment

Opschoor JB (1995) Ecospace and the fall and rise of throughput intensity. Ecol Econ 15(2):137-141

Opschoor JB (2009) Sustainability. In: Peil J, van Staveren I (eds) Handbook of economics and ethics. Edward Elgar Publ, Cheltenham

Ostrom E (1990) Governing the commons: the evolution of institutions for collective action. Cambridge University Press, Cambridge

Ott HE, Winkler H, Brouns B, Kartha S et al (2004) South-North dialogue on equity in the greenhouse: a proposal for an adequate and equitable global climate agreement. GTZ and Wuppertal Institute for Climate, Environment and Energy and Energy Research Centre (UCT). Eschborn (Ger)

OXFAM (2007) Adaptation to climate change: what's needed in poor countries and who should pay. OXFAM Briefing Paper No 104

OXFAM (2008) Climate, poverty and justice: what the Poznan UN climate conference needs to deliver for a fair and effective global climate regime. OXFAM Briefing Paper No 124

Pacala S, Socolow R (2004) Stabilization wedges: solving the climate problem for the next 50 years with current technologies. Science 305:968-972

Parikh JK, Parikh K (2001) Climate change: India's perceptions, positions policies and possibilities. OECD: Cimate and Development, Paris

Pendleton A, Retallack S (2009) Fairness in global climate change finance. Institute for Public Policy Research, London

Pigou AC (1920) The economics of welfare. MacMillan Student Edition

Polanyi K (1944) The great transformation: the political and economic origins of our time. Beacon Press by arrangement with Rinehart \& Company, Inc, Boston

Rice J (2007) Ecological unequal exchange: international trade and uneven utilization of environmental space in the world system. Social Forces

Sachs J (2008) Common wealth: economics for a crowded planet. Penguin Books, New York

Sachs W et al (2002) The Johannesburg memo: fairness in a fragile world; memorandum for the world summit on sustainable development. Heinrich Böll Foundation, Berlin

Siebert H (1982) Nature as a life support system: renewable resources and environmental disruption. J Econ 42(2):133-142

South Centre (2007) Integrating development in climate change: a framework policy discussion paper on key elements for the development of the post-2012 global climate policy regime. South Centre Special Policy Discussion Papers, Geneva

Stern N (2008) Key elements of a global deal on climate change. London School of Economics, London

Stern N et al (2006) The economics of climate change. http://www.hm-treasury.gov.uk

UNDP (2002) Deepening democracy in a fragmented world. Human Development Report 2002. Palgrave (for UNDP), New York

UNDP (2003) Millennium development goals: a compact among nations of end human poverty. Human Development Report 2003. Palgrave (for UNDP), New York

UNDP (2007) Fighting climate change: human solidarity in a divided world. Human Development Report 2007/2008. Palgrave (for UNDP), New York

UNEP (2008) Background paper on green jobs. UNEP, Nairobi

UNEP (2009) Global green new deal. UNEP (and others), Nairobi

UNFCCC (1992) Framework convention on climate change

UNFCCC (2007) Bali action plan. Decision -?CP.13, Bali, www.FCCC.int

WCC (World Council of Churches) (2000) The earth's Atmosphere: responsible caring and equitable burden sharing for a global commons. Statement prepared in anticipation of the 6th Session of the Conference of Parties (COP6) to the UN Framework Comnvention on Climate Change, The Hague, Netherlands, WCCC: Geneva

WCED (World Commission on Environment and Development) (1987) Our common future. Oxford University Press, Oxford

Weterings RAPM, Opschoor JB (1992) The ecocapacity as a challenge to technological development. Raad voor het Milieu- en Natuuronderzoek, no 74a, Rijswijk/Den Haag

Zoellick RB (2008) Modernizing multilateralism and markets. Presentation to Board of Governors of the World Bank Group, World Bank, Washington 